\title{
REVERSIBLE CONTRACEPTIVE POTENTIAL OF HARAD IN MALE ALBINO MICE
}

\author{
PRAKASH CHANDRA GUPTA
}

Department of Zoology, Kashi Naresh Government Post Graduate College, Gyanpur, Bhadohi (221304), Uttar Pradesh, India Email: prakashcgzoology@rediffmail.com

Received: 13 Oct 2016 Revised and Accepted: 26 Nov 2016

\begin{abstract}
Objective: Developing a male contraceptive of plant origin has always been of great interest among researchers. The aim of present investigation was to evaluate the contraceptive potential of Terminalia chebula R. (Harad) with respect to dose and reversibility in male albino mice.

Methods: Aqueous bark extract of Harad was administered orally at 100 (G III), 300 (G IV) and 500 (G V) mg/kg b.w. to males for 35 d, and the effect on histology of testis and accessory sex organs, enzymes 3ß-and 17ß-HSDs, SOD, catalase and LPO levels, sialic acid and fructose levels, sperm parameters, serum testosterone and fertility parameters was determined. Toxicological and recovery studies (G VI and VII) were also carried out.

Results: Harad-treated mice showed dose-related histological alterations in reproductive organs with reductions in weights, the height of germinal epithelium, germ cell number and diameter of stage VII tubules, along with adverse effect on biochemical and sperm parameters compared to controls. No alterations were noticed in SOD, catalase and LPO levels, though, mice in G V showed an increased LPO level. Libido was not affected, but fertility suppressed significantly in Harad-treated males (G VI) compared to controls. However, $42 \mathrm{~d}$ after treatment withdrawal, alterations in reproductive end points and fertility recovered to control levels. Body and organ weights, histo-architecture of vital organs, levels of ALT, AST and creatinine, and hematological parameters remained unchanged.
\end{abstract}

Conclusion: The results suggest that Harad causes dose-dependent reversible contraception in mice without any toxicity.

Keywords: Harad, Testosterone, Spermatogenesis, Epididymis, Fertility

(C) 2017 The Authors. Published by Innovare Academic Sciences Pvt Ltd. This is an open access article under the CC BY license (http://creativecommons.org/licenses/by/4. 0/) DOI: http://dx.doi.org/10.22159/ijpps.2017v9i1.15638

\section{INTRODUCTION}

In India, as well as across the world, developing an orally active, safe, reversible and effective herbal male contraceptive with no adverse effect on libido has always been a matter of great interest among researchers. This might be due to limitations of contraceptive options (condoms, hormonal and non-hormonal regimes, surgical and immunological approaches) presently available for male fertility control, and also because of its ready availability, cost effectiveness and most importantly protection of privacy $[1,2]$.

Although plants have been used to control the fertility of male and female partners since ancient time, the discovery of gossypol (isolated from the cotton plant, Gossypium species) as a male contraceptive by Chinese scientists probably forced scientists to investigate other medicinal plants with antifertility effects [3]. In the recent past, a variety of preparations and active principles from different parts of the plants like seeds, stem, leaves, flowers, root or stem barks, etc. have been searched out in different animal models by researchers to determine their impact on male fertility [4-8]. The biologically active and ecofriendly substances in plant preparations exhibit contraceptive effects in males due to spermicidal actions, suppression of spermatogenesis, altered forward motility and fertilising abilities of spermatozoa $[9,10]$.

Harad (Terminalia chebula (R.): family Combretaceae) is a wellknown evergreen tree in India and Southeast Asia. It has additional local names such as Black Myroblans, Haritaki, Karkchettu, Kadukkaya, Harada etc., and has traditionally been used as a popular folk medicine in homeostatic, antitussive, laxative, diuretic, and cardiotonic treatments. Further, Terminalia chebula (T. chebula) has been reported to show a variety of biological properties like antibacterial [11-15], antifungal [16], antiviral [17-19], anticancer $[20,21]$, antidiabetic [22-24] etc., which could be due to presence of a variety of phytoconstituents like tannins, flavonoids, triterpenoids, glycosides etc. T. chebula is fairly rich in different tannins (approximately 32\% tannin content) such as chebulic acid chebulinic acid, chebulagic acid, gallic acid, corilagin and ellagic acid [25]. In spite of such a vast variety of biological actions, the available literature on Harad lacks information regarding the effect of this plant on the reproductive organs in males except a few [26], and those from our laboratory in initial studies [27, 28].

The aim of the present investigation was to evaluate the contraceptive potential of Terminalia chebula R. (Harad) with respect to dose and reversibility in male albino mice.

\section{MATERIALS AND METHODS}

\section{Collection and authentication of plant material}

Fresh bark of Harad was collected during the summer season from the campus of Banaras Hindu University, Varanasi after its scientific identification and authentication by the Department of Botany. The sample of the plant material was preserved in the herbarium and kept in the museum (Ref No. TC/PCG-D0Z/05/2005) of the Department of Dravyaguna, Faculty of Ayurveda of Banaras Hindu University, Varanasi for future reference.

\section{Preparation of plant extract}

Plant extract was prepared strictly according to WHO protocol [29]. In brief, the bark of Harad was washed properly with sterile distilled water, shade dried for one week, and then ground into fine powder with an electric grinder. The powdered material $(100 \mathrm{~g})$ was extracted with sterile distilled water $(1000 \mathrm{ml}, \mathrm{w} / \mathrm{v} 1: 10)$ in a soxhlet apparatus for $8 \mathrm{~h}$ in a glass vessel, and then cooled to room temperature and filtered. The filtrate was concentrated in an oven at $40{ }^{\circ} \mathrm{C}$ and finally lyophilized to get a black extract which was stored at $4{ }^{\circ} \mathrm{C}$ in a refrigerator. The yield of the extract was approximately $20 \mathrm{~g}$ per $100 \mathrm{~g}(20 \%)$ of the raw bark powder.

\section{Chemicals and reagents}

All chemicals and reagents used in the present investigation were of analytical grade (Merck Life Sciences Pvt. Ltd. Mumbai, India) and were purchased from local commercial vendors. Serum level of creatinine was estimated using a commercial kit (Span Diagnostics Ltd., Surat, India), while that of testosterone was determined by 
radioimmunoassay (Immunotech, Marseille, France). The sensitivity of the radioimmunoassay was $0.025 \mathrm{ng} / \mathrm{ml}$ with an intra-and interassay coefficient of variations being as $14.8 \%$ and $15 \%$ respectively.

\section{Animals}

A total of 42 adults (age 12-14 w) male laboratory albino mice (Mus musculus) of the Parkes (P) strain, weighing 28-38 g, were used in the investigation. Animals were procured from a randomly bred colony maintained in our animal room under standard conditions (temperature $23 \pm 2{ }^{\circ} \mathrm{C}$, photoperiod $12 \mathrm{~h}$ and relative humidity
$50 \pm 20 \%$ with proper ventilation) in polypropylene cages ( $450 \mathrm{~mm} \mathrm{X}$ $270 \mathrm{~mm} \times 150 \mathrm{~mm}$ ) having dry rice husk as the bedding material. Animals were given standard pellet feed (Mona Laboratory Animal Feeds, Varanasi) and fresh drinking tap water ad libitum. All animal experiments were performed following the guidelines of Indian National Science Academy, New Delhi [30].

\section{Experimental design}

Mice were randomly allocated into seven groups, each comprising six individuals, and treated as follows:

Table 1

\begin{tabular}{|c|c|c|c|}
\hline Groups (G) & Treatments & Duration & Autopsy (after last treatment) \\
\hline I & Untreated controls & & \\
\hline II & Distilled water-treated controls & $35 \mathrm{~d}$ & $24 \mathrm{~h}$ \\
\hline III & Harad at $100 \mathrm{mg} / \mathrm{kg}$ b.w. & $35 \mathrm{~d}$ & $24 \mathrm{~h}$ \\
\hline IV & Harad at $300 \mathrm{mg} / \mathrm{kg}$ b.w. & $35 \mathrm{~d}$ & $24 \mathrm{~h}$ \\
\hline V & Harad at $500 \mathrm{mg} / \mathrm{kg}$ b.w. & $35 \mathrm{~d}$ & $24 \mathrm{~h}$ \\
\hline VI, Harad recovery & Harad at $500 \mathrm{mg} / \mathrm{kg}$ b.w. & $35 \mathrm{~d}$ & $42 \mathrm{~d}$ \\
\hline VII, Control recovery & Distilled water-treated controls & $35 \mathrm{~d}$ & $42 \mathrm{~d}$ \\
\hline
\end{tabular}

Aqueous bark extract of Harad was suspended in sterile distilled water and administered orally at the doses of 100,300 and $500 \mathrm{mg} / \mathrm{kg}$ b.w. daily to mice in groups III-VI for $35 \mathrm{~d}$, using an oral feeding needle. The doses, duration and the kind of extract for Harad treatment was selected based on pilot studies conducted in our laboratory in albino mice. Animals in control groups II and VII received orally an equivalent volume of sterile distilled water $(0.5 \mathrm{ml} / 100 \mathrm{~g}$ b.w. daily). The body weight and general health condition of animals were regularly monitored throughout the treatment period.

\section{Autopsy schedule}

At the end of the treatment schedule, animals in groups I (untreated) and II (distilled water-treated) were sacrificed with those in treated groups III-V, while animals in groups VI (Harad recovery) and VII (control recovery) were sacrificed together by decapitation after recording their final body weights. The testis, epididymis, vas deferens, seminal vesicle, ventral prostate, brain, liver, kidney, adrenal gland and spleen were excised, cleared off fat and connective tissue, and weighed to nearest $0.1 \mathrm{mg}$. The testes, epididymes and seminal vesicles from five animals in each group were stored at $-70{ }^{\circ} \mathrm{C}$ for biochemical assays. Trunk blood was collected, and the serum was separated out and stored at- $70{ }^{\circ} \mathrm{C}$ for determination of serum levels of alanine aminotransferase (ALT), aspartate aminotransferase (AST), creatinine and testosterone.

\section{Sperm analyses}

At autopsy, cauda epididymidis was taken out randomly from left or right sides of each of five animals in each group and placed in a watch glass containing $0.5 \mathrm{ml}$ of $0.9 \%$ physiological saline maintained at $37^{\circ} \mathrm{C}$ on a hot plate $[31,28]$. The tissue was minced properly and the sperm suspension, free of tissue debris, was used for analyses of motility, viability, and a number of spermatozoa according to WHO protocol [32] A drop of sperm suspension was smeared on a clean glass slide and observed under a phase contrast microscope to study the morphological alterations in live spermatozoa. The criteria of Wyrobek and Bruce [33] and Zaneveld and Polakoski [34] were employed for evaluation of sperm abnormalities.

\section{Tissue biochemistry}

\section{Sialic acid estimation in epididymis}

The level of sialic acid in the epididymis was estimated according to Aminoff's thiobarbituric acid method [35] and calculated by using Warren's equation 2 [36].

\section{Fructose estimation in seminal vesicle}

The level of fructose in the seminal vesicle was estimated by the method of Lindner and Mann [37] with minor modifications [38].

\section{Determination of oxidative stress in testis}

The levels of the protein [39], lipid peroxidation (LPO) [40] and activities antioxidant enzymes, super-oxide dismutase (SOD) [41] and catalase [42], were assessed to determine the status of oxidative stress in the testis.

\section{Estimation of testicular activities of 3ß-and 17ß-HSDs}

The enzyme activities of $3 ß$-hydroxysteroid dehydrogenase ( $3 ß-$ HSD) [43] and 17ß-hydroxysteroid dehydrogenase (17ß-HSD) [44] were determined biochemically in the testis.

\section{Assay of serum testosterone}

All serum samples were processed in duplicates as per instructions of the manufacturer for quantification of testosterone in a single assay.

\section{Toxicological studies}

\section{Hematology}

Hematological tests for blood cell counts (RBC and WBC), hemoglobin $(\mathrm{Hb})$ and hematocrit $(\mathrm{Hct})$ were performed with the fresh blood, collected after decapitation, according to standard laboratory procedures [45]. The mean corpuscular volume (MCV), mean corpuscular hemoglobin $(\mathrm{MCH})$, and mean corpuscular hemoglobin concentration (MCHC) were also evaluated.

\section{Liver and kidney functions tests}

Serum levels of ALT, AST [46] and creatinine were estimated to determine the functional status of liver and kidney.

\section{Histological techniques}

For histological studies, testis, epididymis, vas deferens, seminal vesicle, prostate gland, a portion of liver, kidney, adrenal gland, and spleen were excised out randomly from the left or right sides of animals $(n=5)$ in each group, fixed in freshly prepared aqueous Bouin's fluid for $3 \mathrm{~h}$, dehydrated in graded ethanol series, cleared in benzene, and embedded in paraffin wax $\left(60-62{ }^{\circ} \mathrm{C}\right)$. Tissues were sectioned at $6 \mu \mathrm{m}$, and sections were stained with periodic acid-Schiff (PAS) and counterstained with Harris hematoxylin. The stained sections were examined under a Leitz (Germany) light microscope.

Histological alterations and stages of spermatogenesis in seminiferous tubules in mouse testis were identified according to criteria described by Russell et al. [47]. To study the treatmentinduced quantitative alterations in spermatogenesis, percent frequency of affected seminiferous tubules was calculated by observing the total tubules from randomly selected testis sections; the diameter of the seminiferous tubules and the height of the germinal epithelium were measured in stage VII tubules $(n=10)$ from each of six mice per group. The treatment-induced alterations in the kinetics of spermatogenesis were determined by identifying a total of hundred seminiferous tubules with respect to the stages (grouped as I-IV, V-VI, VII-VIII, IX-X, XI-XII and unidentifiable) in randomly selected testis sections from each of six mice per group 
[47]. Further, the germ cell number (viz., spermatogonia type A, preleptotene spermatocytes, pachytene spermatocytes, and Step 7 spermatids) at stage VII of the spermatogenic cycle was also determined from five randomly selected stage VII tubules in a testis section from each mouse $(n=5)$. The crude count of different germ cell types was corrected using Abercrombie formula [47, 48].

Epididymis, seminal vesicle, prostate gland, liver, kidney, adrenal gland and spleen were also processed for histological studies. The epididymis was divided into five (I-V) segments for study of treatment-induced histological alterations [49].

\section{Fertility tests}

A total of 10 adults (age 12-14 w) male and 40 female mice of proven fertility were employed in the fertility test. The fertility of males $(\mathrm{n}=5)$ from groups VI (Harad-treated, $500 \mathrm{mg} / \mathrm{kg}$ b.w. for 35 d) and VII (distilled water treated for $35 \mathrm{~d}$ ) was tested at $24 \mathrm{~h}, 2,4$ and $6 \mathrm{w}$ after the last treatment by allowing each male to cohabit overnight with a coeval, virgin female in proestrus, showing regular cycles. Positive mating was confirmed next morning by the presence of a vaginal plug in mated female.

After $12 / 13 \mathrm{~d}$ of gestation, pregnant females were autopsied to record the total number of implants in both the uteri and a total number of corpora lutea in both the ovaries. The resorption sites were counted after treating the uterus with $10 \%$ ammonium sulphide solution [50].

The males were considered fertile if impregnated females showed live implants. Fertility parameters such as index of libido and index of fertility in males and number of live implants, pre-implantation and post-implantation losses in impregnated females were determined

\section{Statistical analyses}

All data, except those of body weight and fertility tests, were analysed by one-way analysis of variance (ANOVA), followed by Neuman-Keuls' multiple range test for comparison of group means. Data on body weight and fertility tests were analysed by Student's ttest. Values were expressed as mean \pm SEM. Results were considered significant at $\mathrm{p}<0.05$ level.

\section{RESULTS}

\section{Body and organ weights}

Treatment with Harad extract had no impact on the initial and final body weights, and on the general health and behaviour of the animals throughout the period of investigation. Further, absolute and relative weights of the vital body organs (brain, liver, kidney, adrenal gland, and spleen) were not affected compared to controls (data not presented).

Treatment with Harad extract at $500 \mathrm{mg} / \mathrm{kg}$ b.w. (G V) caused a significant reduction in absolute weight of testis, epididymis, seminal vesicle and prostate gland (table 2); relative weight of testis and seminal vesicle also reduced significantly in the above-treated mice compared to controls (table 2). Treatment with lower doses of Harad (G III and IV), on the other, had no significant effect on absolute and relative weights of the above reproductive organs, except the seminal vesicle. However, $42 \mathrm{~d}$ after treatment withdrawal, alterations in weights of the reproductive organs recovered to control levels (table 2).

\section{Sperm parameters}

A significant decrease in the motility, viability and number of spermatozoa, while an increase in the number of morphologically abnormal spermatozoa was noticed in Harad-treated mice (G III-V) compared to controls (table 3 ). Further, all sperm parameters except sperm number were more adversely affected in mice treated with Harad at $500 \mathrm{mg} / \mathrm{kg}$ b.w. (G V) compared to those treated at 100 and $300 \mathrm{mg} / \mathrm{kg}$ b.w. (G III and IV).

However, $42 \mathrm{~d}$ after treatment withdrawal, all sperm parameters except number of abnormal sperm recovered to control levels (table 3).

\section{Tissue biochemistry}

\section{Sialic acid level in epididymis and fructose level in seminal vesicle}

Significant reductions were noticed in the level of sialic acid in epididymes and that of fructose in seminal vesicles of mice treated with Harad extract at 300 and $500 \mathrm{mg} / \mathrm{kg}$ b.w. (G IV and V), but not at $100 \mathrm{mg} / \mathrm{kg}$ b.w. (G III) compared to controls. However, $42 \mathrm{~d}$ after treatment withdrawal, alterations in the levels of sialic acid and fructose in the treated mice recovered to control levels (table 4).

\section{Level of oxidative stress in testis}

No significant alterations were noticed in the testicular activities of SOD and catalase, and the level of LPO (table 4), though, mice treated with Harad extract at $500 \mathrm{mg} / \mathrm{kg}$ b.w. (G V) showed an increased LPO level compared to controls (table 4). However, $42 \mathrm{~d}$ after treatment withdrawal, the level of LPO in treated mice recovered to control levels (table 4)

\section{Testicular activities of 3ß-and 17ß-HSDs}

Significant reductions were found in the testicular activities of $3 ß$ and 17ß-HSDs in Harad-treated mice (G III-V)); however, the activity of $17 ß-H S D$ was not affected at $100 \mathrm{mg} / \mathrm{kg}$ b.w. compared to controls (fig. 1).

Further, $42 \mathrm{~d}$ after treatment withdrawal, the activities of $3 ß$-and $17 ß$-HSDs remained significantly reduced in treated mice compared to controls (fig. 1).

\section{Serum testosterone level}

Remarkable, though, nonsignificant reductions were noticed in serum levels of testosterone in Harad-treated mice (G III-V) compared to controls (fig. 1).

\section{Toxicological studies}

\section{Haematology, liver and kidney functions tests}

No significant alterations were noticed in haematological parameters (RBC, WBC, Hb, Hct, MCV, $\mathrm{MCH}$ and $\mathrm{MCHC}$ ), and in serum levels of ALT, AST and creatinine in treated mice compared to controls (data not presented).

\section{Histological studies}

\section{Testis}

Histological observations of tests in controls (untreated and distilled water-treated) showed normal spermatogenesis in nearly all the seminiferous tubules (fig. 2 A), except in a few (see table 4). On the other hand, nonuniform degenerative alterations were noticed in histoarchitecture of tests in Harad-treated $(100,300$ and $500 \mathrm{mg} / \mathrm{kg}$ b.w. for $35 \mathrm{~d}$ ) mice, since both affected and normal tubules were observed in the same testis sections. Further, some animals showed more severe alterations in their tests than others in the same treated groups (G III-V).

In general, affected seminiferous tubules in treated mice showed loosening of germinal epithelium, intraepithelial vacuolation, exfoliation of germ cells (fig. 2 B-D), presence of spermatids at different stages (particularly stages IX, X, and XI) of spermatogenic cycle in the same tubule, failure of release of mature sperm, phagocytosis of elongated spermatids in the germinal epithelium. Furthermore, the histological alterations in testes were more pronounced in mice treated with Harad at $500 \mathrm{mg} / \mathrm{kg}$ b.w. (G V) compared to those in treated groups III and IV; testes in mice in group $\mathrm{V}$ frequently contained degenerating seminiferous tubules with a few normal ones.

Multinucleate giant cells containing nuclei of spermatocytes or round spermatids with eosinophilic cytoplasm (fig. 2 E), uninucleate giant round spermatids, and pycnotic round spermatids showing marginal condensation of chromatin (fig. $2 \mathrm{C}$ ) were frequently seen in testes of treated mice (G III-V). 
Table 2: Effect of Harad on body and reproductive organ weights

\begin{tabular}{|c|c|c|c|c|c|c|c|c|c|c|c|c|}
\hline \multirow[t]{2}{*}{ Groups/Parameters } & \multicolumn{2}{|l|}{ Body weight } & \multicolumn{2}{|l|}{ Testis } & \multicolumn{2}{|l|}{ Epididymis } & \multicolumn{2}{|c|}{ Vas deferens } & \multicolumn{2}{|c|}{ Seminal vesicle } & \multicolumn{2}{|c|}{ Ventral prostate } \\
\hline & Initial & Final & Absolute & Relative & Absolute & Relative & Absolute & Relative & Absolute & Relative & Absolute & Relative \\
\hline I, Cont & $29.83 \pm 0.54$ & $30.50 \pm 0.89$ & $99.60 \pm 3.01$ & $336.05 \pm 16.24$ & $35.65 \pm 0.92$ & $112.86 \pm 4.14$ & $13.57 \pm 0.61$ & $44.25 \pm 3.31$ & $94.77 \pm 5.54$ & $311.60 \pm 17.63$ & $36.90 \pm 3.64$ & $88.15 \pm 9.14$ \\
\hline II, Control(distilled water) & $30.50 \pm 0.68$ & $31.00 \pm 0.45$ & $101.60 \pm 3.45$ & $320.77 \pm 8.49$ & $39.43 \pm 2.47$ & $125.62 \pm 5.82$ & $15.02 \pm 1.02$ & $49.50 \pm 3.21$ & $85.38 \pm 7.36$ & $276.62 \pm 25.47$ & $34.30 \pm 2.31$ & $110.33 \pm 8.20$ \\
\hline III, $100 \mathrm{mg} / \mathrm{kg} \mathrm{b.w.}$ & $30.83 \pm 1.04$ & $31.00 \pm 0.86$ & $91.58 \pm 3.48$ & $295.32 \pm 8.47$ & $34.87 \pm 1.47$ & $118.19 \pm 7.95$ & $11.45 \pm 0.82$ & $38.73 \pm 2.07$ & $61.32 \pm 4.71^{*}$ & $211.45 \pm 19.85^{*}$ & $28.56 \pm 4.50$ & $98.92 \pm 18.73$ \\
\hline IV, 300 mg/kg b.w. & $32.17 \pm 1.33$ & $31.17 \pm 0.65$ & $98.27 \pm 3.81$ & $322.29 \pm 17.54$ & $38.10 \pm 0.77$ & $125.06 \pm 3.33$ & $14.47 \pm 0.24$ & $48.60 \pm 1.75$ & $58.43 \pm 2.83^{*}$ & $189.87 \pm 10.02 *$ & $25.24 \pm 1.95$ & $83.76 \pm 5.00$ \\
\hline V, 500 mg/kg b.w. & $29.00 \pm 0.45$ & $28.33 \pm 0.56$ & $69.92 \pm 2.74^{*}$ & $245.51 \pm 11.29^{*}$ & $28.42 \pm 0.72^{*}$ & $100.89 \pm 1.15$ & $11.07 \pm 0.47$ & $38.97 \pm 2.04$ & $40.60 \pm 4.75^{*}$ & $143.47 \pm 16.91^{*}$ & $19.72 \pm 2.01^{*}$ & $70.56 \pm 5.53$ \\
\hline VI, Harad recovery & $33.50 \pm 0.67$ & $33.67 \pm 0.92$ & $97.48 \pm 4.31$ & $282.30 \pm 7.91$ & $41.00 \pm 2.44$ & $121.58 \pm 7.62$ & $15.50 \pm 1.05$ & $45.03 \pm 2.90$ & $99.87 \pm 8.29$ & $294.28 \pm 20.64$ & $32.24 \pm 4.00$ & $97.93 \pm 13.27$ \\
\hline VII, Control recovery & $31.17 \pm 0.54$ & $31.83 \pm 0.84$ & $99.77 \pm 2.70$ & $308.72 \pm 8.69$ & $45.02 \pm 4.00$ & $141.54 \pm 12.17$ & $15.07 \pm 1.09$ & $47.37 \pm 3.31$ & $105.15 \pm 15.98$ & $331.62 \pm 49.04$ & $32.60 \pm 2.67$ & $114.46 \pm 16.48$ \\
\hline
\end{tabular}

Values are mean \pm SEM for six animals; absolute weight refers to the real weight of the unpaired organ, while relative weight refers to organ weight $/ 100 \mathrm{~g}$ b.w. of animal, ${ }^{*}$ significantly ( $<<0.05$ ) different from controls.

Table 3: Effect of Harad on motility, viability, morphology and number of spermatozoa in cauda epididymidis

\begin{tabular}{llll}
\hline Groups/Parameters & Motility (\%) & Viability (\%) & Abnormal morphology (\%) \\
\hline I, Control(Untreated) & $84.89 \pm 1.02$ & $85.62 \pm 1.92$ & $26.19 \pm 1.63$ \\
II, Control(distilled water) & $86.18 \pm 2.23$ & $88.14 \pm 1.35$ & $24.52 \pm 2.68$ \\
III, $100 \mathrm{mg} / \mathrm{kg}$ b.w. & $55.06 \pm 5.45^{*}$ & $62.62 \pm 3.60^{*}$ & $44.31 \pm 6.30^{*}$ \\
IV, 300 mg/kg b.w. & $67.97 \pm 2.06^{*}$ & $71.89 \pm 2.74^{*}$ & $50.21 \pm 5.74^{*}$ \\
V, 500 mg/kg b.w. & $24.54 \pm 1.73^{\mathrm{a}}$ & $24.54 \pm 1.63^{\mathrm{a}}$ & $81.42 \pm 3.08^{\mathrm{a}}$ \\
VI, Harad recovery & $74.69 \pm 1.64$ & $75.42 \pm 2.33$ & $42.28 \pm 5.83^{\mathrm{c}}$ \\
VII, Control recovery & $83.78 \pm 3.01$ & $84.41 \pm 1.06$ & $24.70 \pm 1.61$ \\
\end{tabular}

Values are mean $\pm S E M$ for five animals; * significantly ( $\mathrm{p}<0.05)$ different from controls; a significantly $(\mathrm{p}<0.05)$ different from controls and those in groups III and IV; ${ }^{\mathrm{s}}$ significantly ( $\left.\mathrm{p}<0.05\right)$ different from recovery controls.

Table 4: Effect of Harad on sialic acid in epididymis, fructose in seminal vesicle, activities of SOD, catalase and LPO level in testis

\begin{tabular}{|c|c|c|c|c|c|}
\hline Groups/Parameters & Sialic acid level ( $\mu \mathrm{mol} / 100 \mathrm{~g}$ tissue) & Fructose level $(\mu \mathrm{g} / \mathbf{1 0 0} \mathrm{mg}$ tissue $)$ & SOD(U/mg protein) & Catalase(Pkat/mg protein) & LPO level(nmol TARS/g tissue) \\
\hline I, Control(Untreated) & $149.56 \pm 13.73$ & $174.64 \pm 9.95$ & $7.88 \pm 0.70$ & $42.42 \pm 6.34$ & $11.34 \pm 2.62$ \\
\hline II, Control(distilled water) & $136.80 \pm 9.82$ & $226.23 \pm 25.58$ & $7.85 \pm 1.31$ & $43.84 \pm 3.87$ & $9.56 \pm 1.81$ \\
\hline III, 100 mg/kg b.w. & $109.62 \pm 7.46$ & $164.38 \pm 30.23$ & $5.78 \pm 0.97$ & $42.75 \pm 8.01$ & $12.20 \pm 1.61$ \\
\hline IV, 300 mg/kg b.w. & $94.90 \pm 4.22^{*}$ & $114.26 \pm 26.54^{*}$ & $5.80 \pm 0.72$ & $44.32 \pm 6.95$ & $17.02 \pm 3.27$ \\
\hline V, 500 mg/kg b.w. & $81.33 \pm 9.80^{*}$ & $63.44 \pm 12.64^{*}$ & $5.69 \pm 0.70$ & $42.05 \pm 7.39$ & $24.49 \pm 3.66^{*}$ \\
\hline VI, Harad recovery & $103.13 \pm 10.00$ & $214.55 \pm 31.14$ & $5.71 \pm 1.30$ & $31.61 \pm 4.51$ & $14.76 \pm 2.13$ \\
\hline VII, Control recovery & $126.02 \pm 6.87$ & $175.37 \pm 16.89$ & $6.48 \pm 0.72$ & $47.73 \pm 8.54$ & $11.88 \pm 1.15$ \\
\hline
\end{tabular}

Values are mean \pm SEM for five animals; *significantly $(\mathrm{p}<0.05)$ different from controls.

Table 5: Effect of Harad on height of germinal epithelium, diameter of stage VII tubules, number of affected tubules and counts of germ cells in testis

\begin{tabular}{|c|c|c|c|c|c|c|c|}
\hline Groups/Parameters & Height $(\mu \mathrm{m})$ & Diameter $((\mu \mathrm{m})$ & Affected tubules (\%) & Spermatogonia type A & Preleptotene spermatocytes & Pachytene spermatocytes & Step 7 spermatids \\
\hline I, Control(Untreated) & $65.74 \pm 2.75$ & $193.16 \pm 3.43$ & $14.59 \pm 0.86$ & $0.50 \pm 0.016$ & $26.94 \pm 1.39$ & $28.07 \pm 1.30$ & $109.49 \pm 5.27$ \\
\hline II, Control(distilled water) & $68.17 \pm 2.55$ & $199.00 \pm 2.87$ & $13.30 \pm 1.38$ & $0.43 \pm 0.025$ & $22.37 \pm 1.05$ & $32.14 \pm 0.73$ & $108.54 \pm 3.15$ \\
\hline III, $100 \mathrm{mg} / \mathrm{kg}$ b.w. & $56.68 \pm 3.29$ & $193.32 \pm 4.67$ & $28.81 \pm 3.63^{*}$ & $0.55 \pm 0.029$ & $19.88 \pm 1.30^{*}$ & $33.44 \pm 2.10$ & $86.64 \pm 3.85 *$ \\
\hline IV, 300 mg/kg b.w. & $53.24 \pm 3.29^{*}$ & $178.65 \pm 5.58$ & $42.69 \pm 4.22^{*}$ & $0.62 \pm 0.031^{*}$ & $16.68 \pm 0.58^{*}$ & $19.89 \pm 2.10^{*}$ & $61.33 \pm 4.35^{*}$ \\
\hline V, 500 mg/kg b.w. & $38.99 \pm 1.78^{\mathrm{b}}$ & $168.35 \pm 3.34^{*}$ & $95.53 \pm 1.39^{\mathrm{a}}$ & $0.59 \pm 0.069 *$ & $15.72 \pm 1.61^{*}$ & $17.59 \pm 0.79 *$ & $54.40 \pm 2.39^{\mathrm{a}}$ \\
\hline VI, Harad recovery & $60.55 \pm 1.90$ & $202.45 \pm 5.22$ & $29.02 \pm 6.64^{c}$ & $0.46 \pm 0.041$ & $17.13 \pm 1.31^{\mathrm{c}}$ & $22.61 \pm 1.20$ & $79.18 \pm 7.80^{c}$ \\
\hline VII, Control recovery & $69.49 \pm 2.11$ & $199.20 \pm 3.43$ & $14.67 \pm 1.07$ & $0.45 \pm 0.027$ & $24.59 \pm 1.60$ & $27.05 \pm 1.20$ & $110.17 \pm 4.51$ \\
\hline
\end{tabular}

Values are mean \pm SEM for five animals; *significantly $(\mathrm{p}<0.05)$ different from controls; bsignificantly $(\mathrm{p}<0.05)$ different from controls and those in group IV; asignificantly $(\mathrm{p}<0.05)$ different from controls and those in groups III and IV; csignificantly $(\mathrm{p}<0.05)$ different from recovery controls. 
A significant increase in the frequency of affected tubules was noticed in testes of Harad-treated mice (G III-V) compared to controls, and this increase was comparatively much higher in mice in group V than those in groups III and IV (table 5). Significant reduction in the height of the germinal epithelium was noticed in testes at higher doses (300 and $500 \mathrm{mg} / \mathrm{kg}$ b.w.) of Harad; further, the diameter of stage VII tubules reduced significantly only in mice in group V compared to controls (table 5). Significant reductions were noticed in the number of preleptotene/pachytene spermatocytes and step 7 spermatids in testes of Harad-treated mice ( $\mathrm{G}$ III-V) compared to controls, except the number of pachytene spermatocytes in mice in group III; the reduction in number of step 7 spermatids was much more pronounced in mice in group V compared to those in groups III and IV (table 5). Further, a significant increase was noticed in a number of spermatogonia type A in testes of treated mice, except in those in group III, compared to controls (table 5). Treatment with Harad extract caused significant reduction in the frequency of early stages (I-IV, V-VI and VII-VIII) of spermatogenic cycle (data not presented) compared to controls; further, the frequency of tubules in stages VII-VIII was reduced remarkably in mice in group $\mathrm{V}$ compared to those in groups III and IV (data not presented). However, $42 \mathrm{~d}$ after treatment withdrawal, histological alterations in testes recovered almost to controls (fig. 2 F), though, the frequency of affected tubules remained elevated, and the number of pachytene spermatocytes and step 7 spermatids remained decreased in testes of treated mice compared to controls (table 5).

\section{Epididymis and vas deferens}

The epididymal segments (I-V) in controls exhibited normal histological features (fig. 3 A-E). Treatment with Harad extract brought degenerative alterations in epididymides that were more severe in mice in group V compared to those in groups III-IV. In epididymes in Harad-treated mice, segments I-III were nearly normal, except that the tubular lumen was either empty or contained sperm fragments and/or exfoliated germ cells with PASpositive materials (fig. $3 \mathrm{~F}-\mathrm{H}$ ); epithelial cells in segments IV and V showed vacuolization and lumen was filled with relatively less sperm or sperm fragments and/or exfoliated germ cells with PASpositive materials; stroma was increased in segment V (fig. $3 \mathrm{I}-\mathrm{J}$ ). Histologically, not much alteration was noticed in vas deferens except the presence of relatively less sperm/sperm fragments in treated mice compared to controls (fig. not shown). However, $42 \mathrm{~d}$ after treatment withdrawal, histological alterations in epididymes and vas deferens recovered to controls (fig. not shown)

\section{Seminal vesicle and prostate gland}

Histologically, seminal vesicles and prostate glands in controls showed normal features (fig. $4 \mathrm{~A}$ and $\mathrm{C}$ ), but in Harad-treated mice (G III-V) reductions in height and number of mucosal folds of the secretory epithelium, and increase in calcareous secretion in the glandular lumen were noticed compared to controls (fig. 4 B and D). However $42 \mathrm{~d}$ after treatment withdrawal, histological alterations in seminal vesicle and prostate gland recovered to controls (fig. not shown)

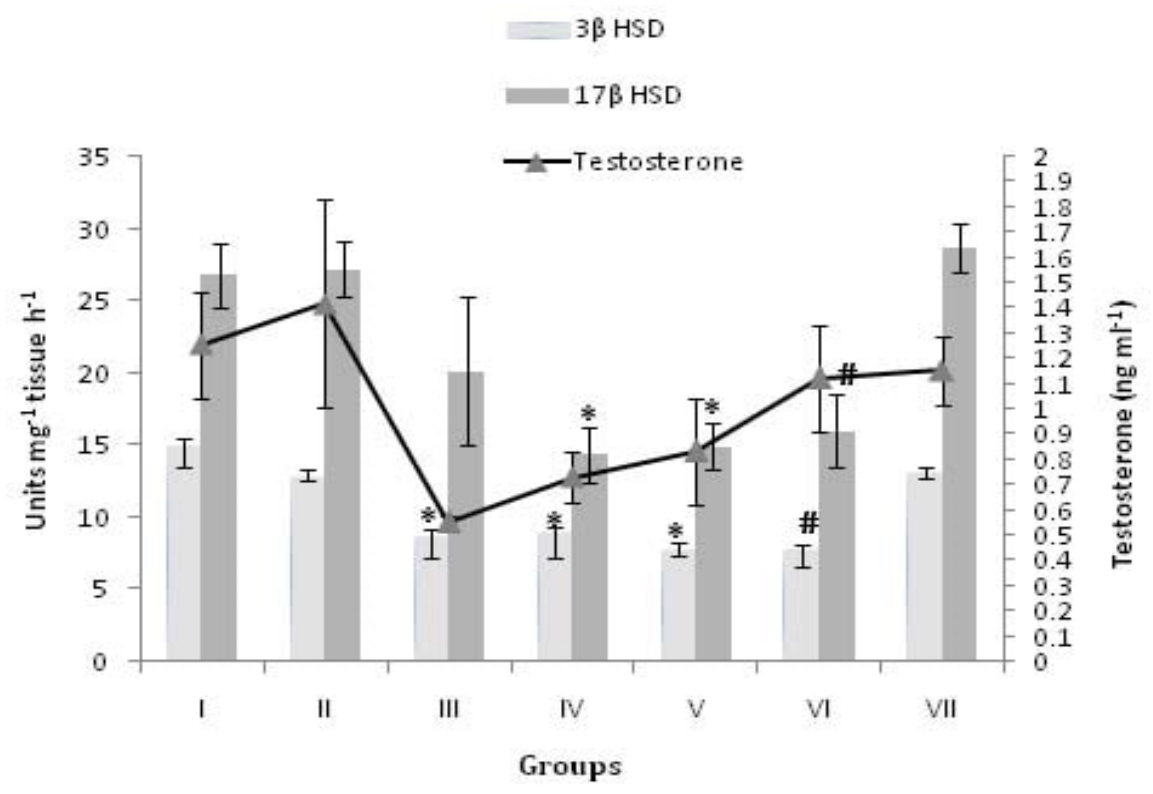

Fig. 1: Effect of Harad on activities of 3ß-and 17ß-HSDs in testis and on serum level of testosterone. Values are mean \pm SEM for five animals. *Significantly $(p<0.05)$ different from controls; "significantly $(p<0.05)$ different from recovery controls

Table 6: Effect of Harad on fertility of males and pregnancy outcome in impregnated females

\begin{tabular}{|c|c|c|c|c|c|c|c|c|c|c|c|c|}
\hline \multicolumn{2}{|c|}{$\begin{array}{l}\text { Time after cessation of } \\
\text { treatment/Parameters }\end{array}$} & \multicolumn{3}{|c|}{$\begin{array}{l}\text { Number of } \\
\text { males }\end{array}$} & \multicolumn{3}{|c|}{$\begin{array}{l}\text { Number of } \\
\text { females }\end{array}$} & \multirow{2}{*}{$\begin{array}{l}\text { Index of } \\
\text { libido } \\
(\%)\end{array}$} & \multirow{2}{*}{$\begin{array}{l}\text { Pre- } \\
\text { implantation } \\
\text { loss }(\%)\end{array}$} & \multirow{2}{*}{$\begin{array}{l}\text { Post- } \\
\text { implantation } \\
\text { loss }(\%)\end{array}$} & \multirow[t]{2}{*}{$\begin{array}{l}\text { Number of } \\
\text { live implants }\end{array}$} & \multirow[t]{2}{*}{$\begin{array}{l}\text { Index of } \\
\text { fertility (\%) }\end{array}$} \\
\hline & & $\mathbf{T}$ & $\mathbf{M}$ & $\mathbf{F}$ & $\mathbf{T}$ & $\mathbf{M}$ & $\mathbf{P}$ & & & & & \\
\hline \multirow[t]{2}{*}{$24 \mathrm{~h}$} & Control & 5 & 5 & 5 & 5 & 5 & 5 & 100 & $3.64 \pm 3.64$ & $7.94 \pm 5.59$ & $8.20 \pm 0.97$ & 100 \\
\hline & Treated & 5 & 5 & 0 & 5 & 5 & 0 & 100 & $100.00 \pm 0.0^{*}$ & 0.0 & $\mathrm{Nil}^{*}$ & $\mathrm{Nil}^{*}$ \\
\hline \multirow[t]{2}{*}{$2 \mathrm{w}$} & Control & 5 & 5 & 5 & 5 & 5 & 5 & 100 & $10.71 \pm 6.10$ & $1.82 \pm 1.82$ & $9.20 \pm 0.49$ & 100 \\
\hline & Treated & 5 & 5 & 0 & 5 & 5 & 0 & 100 & $100.00 \pm 0.0^{*}$ & 0.0 & $\mathrm{Nil}^{*}$ & $\mathrm{Nil}^{*}$ \\
\hline \multirow[t]{2}{*}{$4 w$} & Control & 5 & 5 & 5 & 5 & 5 & 5 & 100 & $6.67 \pm 4.08$ & $4.22 \pm 2.59$ & $9.60 \pm 0.51$ & 100 \\
\hline & Treated & 5 & 5 & 1 & 5 & 5 & 3 & 100 & $85.56 \pm 7.12^{*}$ & $40.00 \pm 24.49$ & $0.60 \pm 0.60^{*}$ & $20.00 \pm 20.00 *$ \\
\hline \multirow[t]{2}{*}{$6 \mathrm{w}$} & Control & 5 & 5 & 5 & 5 & 5 & 5 & 100 & $6.74 \pm 2.99$ & 0.0 & $10.00 \pm 0.63$ & 100 \\
\hline & Treated & 5 & 5 & 5 & 5 & 5 & 5 & 100 & $24.75 \pm 9.46$ & $11.94 \pm 5.60$ & $7.00 \pm 1.05$ & 100 \\
\hline
\end{tabular}

T-Tested; M-Mated; F-Fertile; and P-Pregnant, Values are mean \pm SEM for five animals; *significantly ( $<<0.05)$ different from controls, Index of libido $=$ (number mated/number paired) X 100; Index of fertility = (number of males siring live implants/number mated) X 100; Pre-implantation loss = (total number of corpora lutea-total number of implantations/total number of corpora lutea) X 100; Post-implantation loss = (total number of implantations-total number of viable implantation/total number of implantations) X 100 


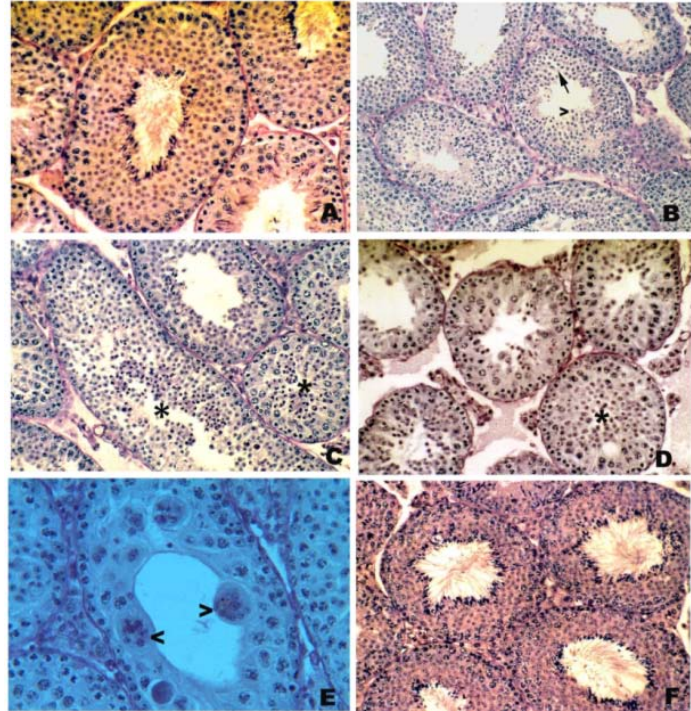

Fig. 2: PAS-hematoxylin stained sections of mouse testis (Magnifications: A-D and F: X 200; E: X 250). (A) Control is showing normal spermatogenesis in the tubules. (B) After treatment with Harad $(300 \mathrm{mg} / \mathrm{kg} \mathrm{b.w.)}$. to show loosening of germinal epithelium (arrow) and exfoliation of germ cells (arrowhead). (C) After treatment with Harad extract $(500 \mathrm{mg} / \mathrm{kg}$ b.w.) to show exfoliated pycnotic round spermatids (asterisk). (D) and (E) After the same treatment as in (C) to show exfoliation of germ cells and complete absence of elongated spermatids (asterisk) and formation of giant cells (arrowheads). (F) Testis of mice from G VI to show recovery of normal spermatogenesis in tubules

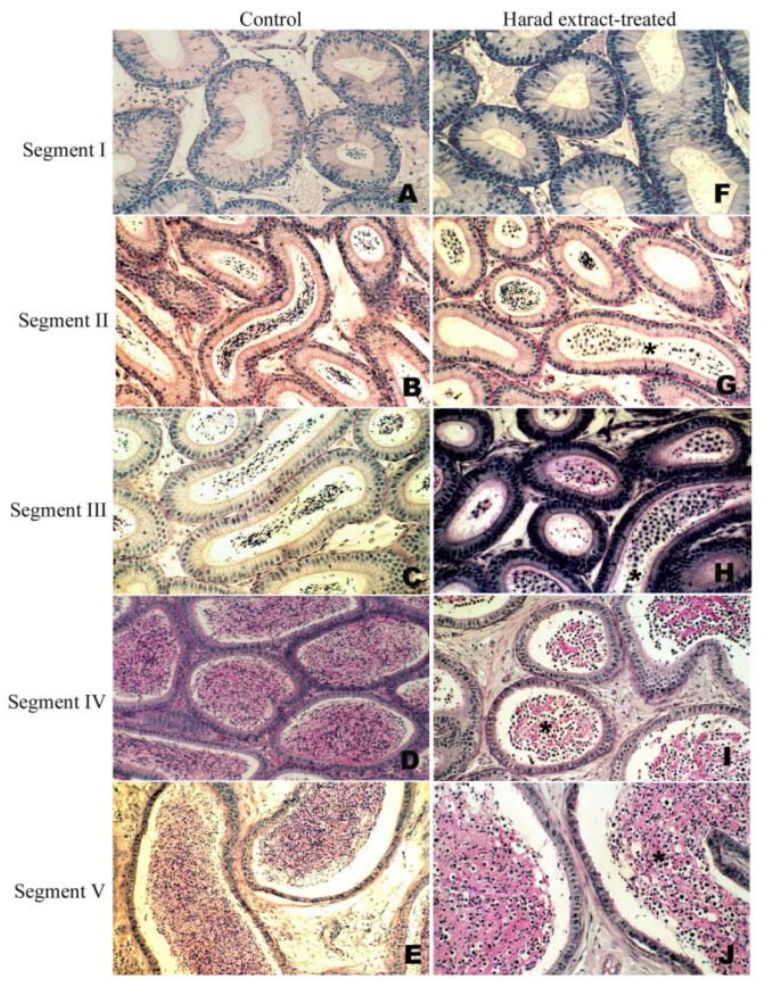

Fig. 3: PAS-hematoxylin stained sections of mouse epididymis (Magnifications: A-E and F-J: X 200). Segments I (A), II (B), III (C), IV (D) and V (E) of control to show normal histological features and lumen containing spermatozoa. Segments I (F), II (G), III (H), IV (I) and V (J) of mice treated with Harad $(500 \mathrm{mg} / \mathrm{kg} \mathrm{b.w.)} \mathrm{to}$ show the normal appearance of the segments, except that the lumen is devoid of spermatozoa and contains sperm fragments and exfoliated germ cells with PAS-positive materials (asterisk)

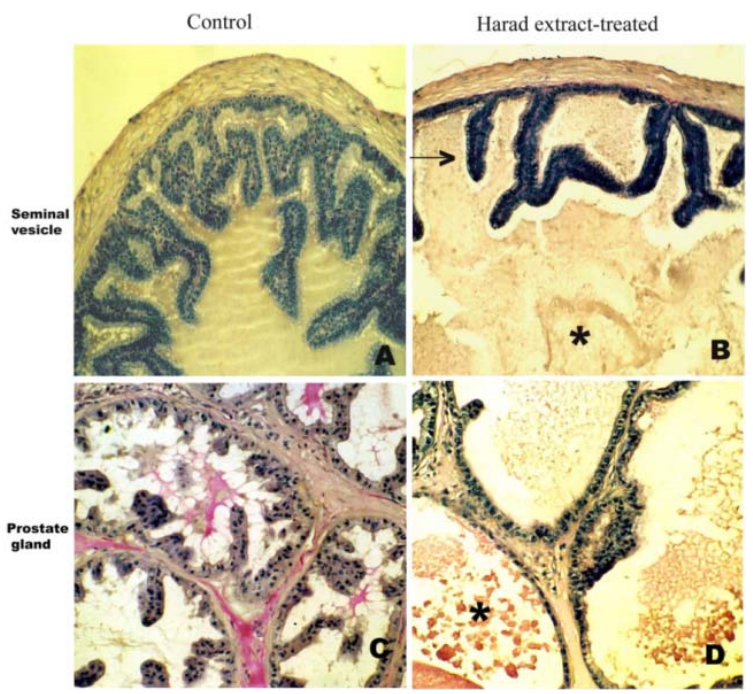

Fig. 4: PAS-hematoxylin stained sections of mouse seminal vesicle and prostate gland (Magnifications: A-D: X 200. (A) Seminal vesicle of control to show normal histological features.

(B) After treatment with Harad (500 mg/ $\mathrm{kg}$ b.w.) to show reduced height of the secretory epithelium, fewer epithelial mucosal folds (arrow) and increased calcareous secretion in the lumen (asterisk). (C) Prostate gland of control to show normal histological features. (D) After treatment with Harad $(500 \mathrm{mg} / \mathrm{kg} \mathrm{b.w.)}$ to show reduced height of the secretory epithelium, fewer epithelial mucosal folds and increased calcareous secretion in the lumen (asterisk)

Liver, kidney, adrenal gland and spleen

No histopathological alterations were noticed in liver, kidney, adrenal gland and spleen in Harad-treated mice compared to controls (fig. not shown).

\section{Fertility test and pregnancy outcome}

When Harad-treated males (G VI: $500 \mathrm{mg} / \mathrm{kg}$ b.w. for $35 \mathrm{~d}$ ) were caged with females at $24 \mathrm{~h}, 2,4$, and $6 \mathrm{w}$ after withdrawal of treatment, libido was not affected at any interval (table 5). The fertility of treated mice, however, was found to be nil at $24 \mathrm{~h}$ and $2 \mathrm{w}$ after treatment withdrawal, since none of the impregnated females showed live implants due to absolute pre-implantation loss; at $4 \mathrm{w}$ after treatment withdrawal, the fertility recovered to $20 \%$ with significantly reduced number of live implants and high preimplantation loss in impregnated females; and ultimately at $6 \mathrm{w}$ after treatment withdrawal, fertility of treated mice recovered to control levels (table 6).

\section{DISCUSSION}

The results of the present study in albino mice indicate that treatment with Harad extract for $35 \mathrm{~d}$ caused dose-dependent reduction in weights of the testis, accompanied with nonuniform histological alterations in tubules such as loosening of germinal epithelium, intraepithelial vacuolation, exfoliation of germ cells, and presence of spermatids at different stages in the same tubule, etc. The severity of treatment induced degenerative alterations in testes varied group to group, and also among the individuals of the same treated group. It is to be noted here that such nonuniform, focal damages in the testis occur because tubules in certain stages of spermatogenesis are more prone to damage than the others [47] by various treatments, as also described in mice after treatment with leaf extract of Colebro oppositifolia [51], bark extract of Albizia lebbeck (L.) Benth [52], 50\% ethanolic extract of Calendula officinalis [53], leaf extract of Ficus bengalensis [54], and several antispermatogenic agents such as Gossypol [55], imino sugars [56], AF 2364 [57] etc. Treatment with Harad extract induced dosedependent suppression of spermatogenesis since mice are treated at $500 \mathrm{mg} / \mathrm{kg} \mathrm{b.w.} \mathrm{(G} \mathrm{V)} \mathrm{showed} \mathrm{more} \mathrm{pronounced} \mathrm{degenerative}$ 
histological alterations accompanied with a higher percentage of affected tubules, more reductions in the height of germinal epithelium, the diameter of stage VII tubules due to significant premature loss of preleptotene/pachytene and step 7 spermatids. Treatment-induced alterations in the frequency of tubules in early stages (especially stages VII-VIII) of spermatogenic cycle suggest the disturbance in the kinetics of spermatogenesis [58]. Further, round spermatids appeared to be the target germ cells in the tubules to the Harad treatment, since these cells often showed marginal condensation of chromatin, premature exfoliation and giant cell formation, as observed in rat testis after treatment with Tamoxifen [59]; furthermore, there was also a marked reduction in the number of step 7 spermatids in stage VII tubule in testes of Harad-treated mice compared to controls.

Treatment with Harad extract at a higher dose caused a significant reduction in absolute weight of the epididymis accompanied with vacuolization and accumulation of PAS-positive inclusions in the epithelial cells of segment IV (corpus) of epididymis as reported in mice following various treatments [28, 52, 54], which could be because of absence or reduced number of sperm in epididymal lumen as described by Abe and his group $[60,61]$. The treatment also had an adverse effect on motility, viability, morphology and number of spermatozoa in cauda epididymidis. Reduction in the sperm number in treated mice is certainly due to suppression of spermatogenesis in the testis since round spermatids were the most affected germ cells as discussed above. On the other hand, alterations in motility, viability and morphology of spermatozoa might have resulted from a testosterone-mediated disturbance in the structure and function of epididymis $[62,63]$ as supported by a dose-dependent reduction in the level of sialic acid [51]. Reductions in weights of testosteronedependent accessory sex glands viz., seminal vesicles and prostate glands accompanied with histological alterations, in addition, reduction in the level of fructose in seminal vesicles in treated mice further strongly support the above hypothesis.

No alterations in activities of antioxidant enzymes, SOD and catalase, suggest that the suppression of spermatogenesis should not be the result of treatment-induced oxidative stress in testes of treated mice. Further, increased level of LPO in mice treated at $500 \mathrm{mg} / \mathrm{kg}$ b.w. could be due to pronounce degenerative alterations in their testes. Therefore, it appears that contraceptive effect of Harad is mediated via hypothalamohypophysial-testis axis either by inhibiting the secretions of gonadotropins especially luteinizing hormone (LH) from the pituitary gland, or of testosterone from Leydig cells. Leydig cells under the influence of LH produce testosterone to support spermatogenesis [64]. In the present study after treatment with Harad extract, the enzyme activities of $3 ß$-and $17 ß$-HSDs were adversely affected which are essential for testosterone biosynthesis in testis. A non-significant reduction in serum levels of testosterone in treated mice supports the above findings. This is to be noted here that a much higher (25-125 fold higher than the serum level) intratesticular level of testosterone is required to maintain spermatogenesis in rodents and human [65, 66], and therefore, in absence or a slight decrease of testosterone, spermatogenesis fails to proceed beyond the meiosis stage. Further, germ cells that have progressed beyond meiosis detach prematurely from Sertoli cells and/or undergo apoptosis [67] as observed in the present study.

Libido was not affected in Harad-treated males, but there was a complete suppression of fertility in males at $24 \mathrm{~h}$ and $2 \mathrm{w}$ after treatment withdrawal due to an absolute pre-implantation loss in the impregnated females. This could be because of severely reduced number and quality of the cauda spermatozoa. At $4 \mathrm{w}$ after treatment withdrawal, the fertility recovered to $20 \%$, and ultimately by $6 \mathrm{w}$ after treatment withdrawal, the fertility of treated mice recovered to control levels. The complete reversal of fertility by $6 \mathrm{w}$ after treatment withdrawal suggests that spermatogonial proliferation was not affected by the treatment, and the spermatogenesis and other reproductive endpoints recovered to normal as observed in the present study.

The absence of any alterations in mean body weights or in weights of brain, liver, kidney, adrenal and spleen, in serum levels of transaminases (ALT and AST) and creatinine, and in haematological indices (data not presented) suggest that the Harad extract did not produce any systemic toxicity in treated mice. This is further supported by the absence of histological alterations in the above vital organs (fig. not shown).

\section{CONCLUSION}

Treatment with Harad extract produced reversible suppression of spermatogenesis and fertility and therefore caused dose-dependent reversible contraception in albino mice without any toxicity

\section{ACKNOWLEDGEMENT}

This work was financially supported by The Council of Scientific and Industrial Research (CSIR-HRDG), New Delhi. The author is thankful to Professor Shio Kumar Singh, Department of Zoology, B. H. U., Varanasi for his valuable guidance, suggestions, and for providing laboratory and animal room facilities.

\section{CONFLICT OF INTERESTS}

Declared none

\section{REFERENCES}

1. Chaudhury RR. The quest for an herbal contraceptive. Natl Med J India 1993;6:199-201.

2. Chaudhury SR, Gupta CM, Kamboj VP. Current status in fertility regulation: indigenous and modern approaches. Lucknow: Central Drug Research Institute; 2001.

3. Frick J, Danner C. Effect of gossypol on human testicular function: evaluation of seminal and hormonal parameters. In: Segal SJ. editor. Gossypol-A potential contraceptive for Men. New York: Plenum Press; 1985. p. 17-23.

4. Lohiya NK, Manivannan B, Mishra PK, Pathak N. Prospects of developing a plant based male contraceptive pill. In: Chowdhury SR, Gupta CM, Kamboj VP. editors. Current Status in Fertility Regulation: Indigenous and Modern Approaches. Lucknow: Central Drug Research Institute; 2001. p. 99-119.

5. Gupta RS, Sharma R. A review on medicinal plants exhibiting antifertility activity in males. Nat Prod Rad 2006;5:389-410.

6. D'Cruz SC, Vaithinathan S, Jubendradass R, Mathur PP. Effects of plants and plant products on the testis. Asian J Androl 2010;12:468-79.

7. Ogbuewu IP, Unamba-Oparah IC, Odoemenam VU, Etuk IF, Okoli IC. The potentiality of medicinal plants as the source of new contraceptive principles in males. North Am J Med Sci 2011;3:255-63.

8. Singh K, Gupta RS. Antifertility activity of $\beta$-sitosterol isolated from Barleria prionitis (L.) roots in male albino rats. Int J Pharm Pharm Sci 2016;8:88-96.

9. Tatli-Cankaya I, Alqasoumi SI, Abdel-Rahman RF, Yusufoglu $\mathrm{H}$, Anul S, Akaydin G, et al. Evaluating the antifertility potential of the ethanolic extracts of Bupleurum sulphureum and Cichorium intybus in male rats. Asian J Pharm Clin Res 2014;7:211-8.

10. Janarthanan R, Chinta G, Jesthadi D, Shanmuganathan B, Periyasamy L. Effect of piperine on goat epididymal spermatozoa: an in vitro study. Asian J Pharm Clin Res 2014;7:57-61.

11. Sato Y, Oketani H, Singyouchi K, Ohtsubo T, Kihara M, Shibata H et al. Extraction and purification of effective antimicrobial constituents of Terminalia chebula $\mathrm{R}$. against methicillin-resistant Staphylococcus aureus. Biol Pharm Bull 1997;20:401-4.

12. Ahmad I, Mehmood Z, Mohammad F. Screening of some Indian medicinal plants for their antimicrobial properties. J Ethnopharmacol 1998;62:183-93.

13. Malekzadeh F, Ehsanifar H, Shahamat M, Levin M, Cilwell RR. Antibacterial activity of black myrobalan (Terminalia chebula R.) against Helicobacter pylori. J Antimicrobial Agents 2001;18:85-8.

14. Kim HG, Cho JH, Jeong EY, Lim JH, Lee SH, Lee HS. The growthinhibiting activity of active component isolated from Terminalia chebula fruits against intestinal bacteria. J Food Prot 2006;69:2205-9.

15. Kannan P, Ramadevi SR, Hopper W. Antibacterial activity of Terminalia chebula fruit extract. Afr J Microbiol Res 2009;3:180-4. 
16. Shinde SL, More SM, Junne SB, Wadje SS. The antifungal activity of five Terminalia species checked by paper disk method. Int J Pharm Res Dev 2011;3:36-9.

17. Ahn MJ, Kim CY, Lee JS, Kim TG, Kim SH, Lee Ck, et al. Inhibition of HIV-1 integrase by galloyl glucoses from Terminalia chebula and flavonol glycoside gallates from Euphorbia pekinensis. Planta Med 2002;68:457-9.

18. Vermani K, Garg S. Herbal medicines for sexually transmitted diseases and AIDS. J Ethnopharmacol 2002;80:49-66.

19. Ma H, Diao Y, Zhao D, Li K, Kang T. A new alternative to treat swine influenza A virus infection: extracts from Terminalia chebula R. Afr J Microbiol 2010;4:497-9.

20. Reddy DB, Reddy TC, Jyotsna G, Sharan S, Priya N, Lakshmipathi $\mathrm{V}$, et al. Chebulagic acid, a COX-LOX dua inhibitor isolated from the fruits of Terminalia chebula R., induces apoptosis in the COLO-205 cell line. J Ethnopharmacol 2009;124:506-12.

21. Ponnusankar S, Pandit S, Babu R, Bandyopadhyay A, Mukherjee PK. Cytochrome P450 inhibitory potential of triphala-a rasayana from ayurveda. J Ethnopharmacol 2011;133:120-5.

22. Rao NK, Nammi S. Antidiabetic and renoprotective effects of the chloroform extract of Terminalia chebula R. seeds in streptozotocin-induced diabetic rats. BMC Complementary Altern Med 2006;6:17.

23. Kumar GPS, Arulselvan P, Kumar DS, Subramanian SP. Antidiabetic activity of fruits of Terminalia chebula on streptozotocin-induced diabetic rats. J Health Sci 2006;52:283-91.

24. Murali YK, Anand P, Tandon V, Singh R, Chandra R, Murthy PS. Long-term effects of Terminalia chebula $\mathrm{R}$. on hyperglycemia and associated hyperlipidemia, tissue glycogen content and in vitro release of insulin in streptozotocin-induced diabetic rats. Exp Clin Endocrinol Diabetes 2007;115:641-6.

25. Gupta PC. Biological and pharmacological properties of Terminalia chebula R. (Haritaki)-An overview. Int J Pharm Pharm Sci 2012b;4:62-8.

26. Srivastav A, Chandra A, Singh M, Jamal E, Rastogi P, Rajendran SM, et al. Inhibition of hyaluronidase activity of human and rat spermatozoa in vitro and antispermatogenic activity in rats in vivo by Terminalia chebula, a flavonoid-rich plant. Reprod Toxicol 2010;29:214-24.

27. Gupta PC, Singh SK. Effect of different extracts of the bark of Terminalia chebula on reproductive organs in male mice. In: ICRH and $20^{\text {th }}$ Annual Meeting of the Indian Society for the Study of Reproduction and Fertility. Jaipur, Rajasthan: ICRH; 2010. p. 40

28. Gupta PC. Study on antispermatogenic and antifertility effects of Terminalia chebula in albino mice. J Biol Nat 2015;3:121-31.

29. World Health Organization. WHO Chemical Guidelines. CG-03, 1001A/iP. Geneva: WHO; 1986.

30. Indian National Science Academy. Guidelines for Care and Use of Animals in Scientific Research. New Delhi: INSA; 2000.

31. Gupta PC. Evaluation of in vitro spermicidal potential of Mimusops elengi L. (Bakul) in wild mice. Indian J Sci 2014;11:7-14.

32. World Health Organization. WHO Laboratory Manual for the Examination of Human Semen and Semen-Cervical Mucus Interaction. Cambridge: Cambridge University Press; 1999.

33. Wyrobek AJ, Bruce WR. Chemical induction of sperm abnormalities in mice. Proc Natl Acad Sci 1975;72:4425-9.

34. Zaneveld L, Polakoski KL. Collection and physical examination of the ejaculate. In: Hafez ESE. editor. Techniques of Human Andrology. New York: Elsevier/North Holland Biomedical Press; 1977. p. 147-72.

35. Aminoff D. Methods for the quantitative estimation of $\mathrm{N}$ acetylneuraminic acid and their application to hydrolysates of sialomucoids. Biochem J 1961;81:384-92.

36. Warren L. The thiobarbituric acid assay of sialic acids. J Biol Chem 1959;234:1971-5.

37. Lindner HR, Mann T. Relationship between the content of androgenic steroids in the testis and the secretory activity of the seminal vesicle in the bull. J Endocrinol 1960;21:341-60.

38. Gupta PC. Herbal approach to male fertility control. Germany: Lap Lambert Academic Publishing; 2012c.
39. Lowry $\mathrm{OH}$, Rosenbourgh MJ, Farr AL, Randall RJ. Protein measurement with the folin phenol reagent. J Biol Chem 1951;193:265-75.

40. Ohkawa H, Ohishi N, Yagi K. Assay for lipid peroxides in animal tissues by thiobarbituric acid reaction. Anal Biochem 1979;95:351-8

41. Das K, Samanata L, Chainy GBN. A modified spectrophotometric assay of superoxide dismutase using nitrite formation by superoxide radicals. Int J Biochem Biotechnol 2000;37:201-4.

42. Aebi H, Catalase. In: Bergmeyer HU. editor. Methods of Enzymatic Analysis. New York: Academic Press; 1974. p. 67384.

43. Talalay P. Hydroxy dehydrogenase. In: Colowick SP, Kaplan NO. editors. Methods in Enzymology. New York: Academic Press; 1962;5:512-6.

44. Jarabak J, Adams JA, Williams-Ashaman HG, Talalay P. Purification of $17 ß$-hydroxysteroid dehydrogenase function. J Biol Chem 1962;237:345-57.

45. Ghai CL, Haematology. In: A textbook of practical physiology. New Delhi: Jaypee Brothers Medical Publishers (P) Ltd.; 1999. p. 2-124.

46. Reitmann S, Frankel S. A colorimetric method for the determination of serum glutamate oxaloacetate and glutamic pyruvic transaminases. Am J Clin Pathol 1957;28:56-63.

47. Russell LD, Ettlin RA, Hikim APS, Clegg ED. Histological and Histopathological Evaluation of the Testis. Clearwater: Cache River Press; 1990.

48. Abercrombie M. Estimation of nuclear population from microtome sections. Anat Rec 1946;94:239-47.

49. Takano H. Qualitative and quantitative histology and histogenesis of the mouse epididymis, with special emphasis on the regional difference. Acta Anat Nippon 1980;55:573-87.

50. Salewski E. Farbemethode zum makroskopischen Nachweis von Implantationsstellen am Uterus der Ratte. NaunynSchmeidebergs Arch Pharmakologie Experimentelle Pathologie 1964;247:367.

51. Gupta RS, Yadav RK, Dixit VP, Dobhal MP. Antifertility studies of Colebro oppositifolia leaf extract in male rats with special reference to cell population dynamics. Fitoterapia 2001;72:236-45.

52. Gupta RS, Kachhawa JB, Chaudhary R. Antispermatogenic antiandrogenic activities of Albizia lebbeck (L.). Benth bark extract in male albino rats. Phytomed 2006;13:277-83.

53. Agarwal M, Sharma $P$, Kushwaha S. Antifertility efficacy of $50 \%$ ethanolic extract of Calendula officinalis in male rats. Int J Pharm Pharm Sci 2011;3:192-6.

54. Gupta PC. A preliminary study on effects of leaf extract of Ficus bengalensis (L.) on spermatogenesis and fertility in albino mice. Int J Pharmtech Res 2012a;4:226-32.

55. Qian SZ, Wang ZG. Gossypol: a potential antifertility agent for males. Annal Rev Pharmacol Toxicol 1984;24:329-60.

56. Van der Spoel AC, Jeya Kumar M, Bulters TD, Charlton HM, Moore HD, Dwek RA, et al. Reversible infertility in male mice after oral administration of alkylated imino-sugars: a nonhormonal approach to male contraception. Proc Natl Acad Sci USA 2002; 99:17173-8.

57. Cheng CY, Mruk D, Silverstini B, Bonanomi M, Wong CH, Siu MK, et al. AF-2364 [1-(2,4-dichlorobenzyl)1H-indazol-3carbohydrazide] is a potent male contraceptive: a review of recent data. Contraception 2005;72:251-61.

58. Hess RA, Schaeffer DJ, Eroschenko VP, Keen JE. The frequency of the stages in the cycle of the seminiferous epithelium in the rat. Biol Reprod 1990;43:517-24.

59. Urban JA D'Souza. Tamoxifen-induced multinucleated cells (symplasts) and distortion of seminiferous tubules in rat testis. Asian J Androl 2003;5:217-20.

60. Abe K, Takano H, Ito T. Response of the epididymal duct to the temporary deletion of spermatozoa induced by testicular irradiation in mice. Anat Rec 1983;207:17-24.

61. Abe K, Takano H. Response of the mouse epididymal duct to the disappearance and reappearance of spermatozoa induced by temporal cryptorchidism. Arch Histol Jap 1987;50:315-24.

62. Rajalakshmi M. Regulation of male fertility: epididymis as a potential extragonadal site. In: Ghosh D, Sengupta J. editors. 
Frontiers in reproductive physiology: New Delhi: Wiley Eastern Limited; 1992. p. 63-6.

63. Cooper TG. The Epididymis as a site of the contraceptive attack In: Nieschlag E, Habenicbt UF. editors. Spermatogenesis, Fertilization, Contraception. Berlin: Springer; 1992. p. 419-60.

64. Arafa NMS. Efficacy of Echinacea on the action of cyproterone acetate in male rats. Pak J Biol Sci 2010;13:966-76

65. Zirkin BR, Santulli R, Awoniyi CA, Ewing LL. Maintenance of advanced spermatogenic cells in the adult rat testis: quantitative relationship to testosterone concentration within the testis. Endocrinology 1989;124:3043-9.
66. Jarow JP, Chen H, Rosner TW, Trentacoste S, Zirkin BR Assessment of the androgen environment within the human testis: minimally invasive method to obtain intratesticular fluid. J Androl 2001;22:640-5.

67. Walker WH. Non-classical actions of testosterone and spermatogenesis. Philos Trans R Soc B 2010;365:1557-69.

\section{How to cite this article}

- Prakash Chandra Gupta. The reversible contraceptive potential of harad in male albino mice. Int J Pharm Pharm Sci 2017;9(1):288-296 